Article

\title{
Synthesis and Effect on Human HepG2 Cells of 1,2-bis- (2-Methylallyl)disulfane
}

\author{
Chunxiao Ji ${ }^{1{ }^{*},}$, Fenglian Ren ${ }^{1}$, Jun Dai ${ }^{1}$ and Ming $\mathrm{Xu}^{2}$ \\ 1 College of Chemistry and Chemical Engineering, Central South University, Changsha, Hunan \\ 410083, China; E-Mail: renfl2009@yahoo.com.cn (F.R.) \\ 2 Research Institute for Molecular Pharmacology and Therapeutics, Central South University, \\ Changsha, Hunan 410083, China
}

* Author to whom correspondence should be addressed; E-Mail: cx312@163.com.

Received: 16 April 2010; in revised form: 11 May 2010 / Accepted: 12 May 2010 /

Published: 18 May 2010

\begin{abstract}
: 1,2-bis(2-methylallyl)disulfane was synthesized from sodium sulfide and 3-chloro-2-methylpropylene. The structure of the target product was confirmed by GC-MS, ${ }^{1} \mathrm{H}-\mathrm{NMR}$ and elemental analysis. Cell viability assay, flow-cytometric analysis and protein expression results showed that 1,2-bis(2-methylallyl)disulfane could significantly inhibit the proliferation, and induce the apoptosis of human HepG2 cells.
\end{abstract}

Key words: 1,2-bis(2-methylallyl)disulfane; identification; apoptosis

\section{Introduction}

Garlic is a kind of liliaceae allium, and allicin is the general name for the main bioactive components of garlic, which is a mixture of a variety of allyl sulfides, including diallytrisulfide compounds (DATS), diallyl disulfide compounds (DADS) and many kinds of thioethers. Allicin has a variety of biological activities [1-6]. At present, there is an abundance of research on various aspects of allicin, and those studies have shown that the DADS, DATS and diallyl sulfur compounds (DAS) in allicin have anti-tumor effects and can inhibit the growth of various tumor cells, such as human colon cancer cells, human liver cells, human gastric cancer cells, and so on [7-11]. 1,2-bis(2-Methylallyl)disulfane exists in natural garlic, and it is one of the bioactive components of allicin, but its content is not very high [12]. In this paper, we have successfully synthesized 1,2-bis(2-methylallyl)- 
disulfane using sodium sulfide and 3-chloro-2-methylpropylene as raw materials, and proved that 1,2-bis(2-methylallyl)disulfane has an antitumor effect.

\section{Results and Discussion}

\subsection{Structural characterization of 1,2-bis(2-methylallyl)disulfane}

\subsubsection{GC-MS analysis results}

The compound was analyzed using GC-MS and the results are quite consistent with the structure of 1,2-bis(2-methylallyl)disulfane. The data are shown in Table 1.

Table 1. GC-MS analysis results.

\begin{tabular}{|c|c|c|c|}
\hline No. & Peaks detected in GC-MS $(\mathrm{m} / \mathrm{z})$ & Possible groups & $\begin{array}{l}\text { Accurate } m / z \text { value for } \\
\text { the proposed groups }\end{array}$ \\
\hline 1 & $39-43$ & $\mathrm{H}_{2} \mathrm{C}=\mathrm{C}-\mathrm{CH}_{2}$ & 40 \\
\hline 2 & $41-43$ & $\mathrm{H}_{2} \mathrm{C}=\left.\right|_{\mathrm{C}} ^{\mathrm{CH}_{3}}$ & 41 \\
\hline 3 & 55 & $\mathrm{H}_{2} \mathrm{C}=\left.\right|_{\mathrm{C}} ^{\mathrm{CH}_{3}}-\mathrm{CH}_{2}$ & 55 \\
\hline 4 & 57 & Not characterized & \\
\hline 5 & 71 & Not characterized & \\
\hline 6 & 81 & Not characterized & \\
\hline 7 & $86-88$ & $\mathrm{H}_{2} \mathrm{C}=\left.\right|_{\mathrm{C}} ^{\mathrm{CH}_{3}}-\mathrm{C}_{\mathrm{C}}^{\mathrm{H}_{2}}-\mathrm{S}$ & 87 \\
\hline 8 & 113 & Not characterized & \\
\hline 9 & $118-121$ & $\mathrm{H}_{2} \mathrm{C}=\left.\right|_{\mathrm{C}} ^{\mathrm{C}_{3}}-\mathrm{C}_{\mathrm{C}}-\mathrm{S}-\mathrm{S}$ & 119 \\
\hline 10 & 133 & $\mathrm{H}_{2} \mathrm{C}=\left.\right|_{\mathrm{C}} ^{\mathrm{CH}_{3}}-\mathrm{C}_{\mathrm{C}}-\mathrm{S}-\mathrm{S}-\mathrm{CH}_{2}$ & 133 \\
\hline 11 & 174 & $\mathrm{H}_{2} \mathrm{C}=\left.\right|_{\mathrm{C}} ^{\mathrm{CH}_{3}}-{ }_{\mathrm{C}}^{\mathrm{H}_{2}}-\mathrm{S}-\mathrm{S}-\mathrm{C}_{\mathrm{C}}^{\mathrm{H}_{2}}-\left.\right|_{\mathrm{C}} ^{\mathrm{CH}_{3}}=\mathrm{CH}_{2}$ & 174 \\
\hline
\end{tabular}

\subsection{2. ${ }^{1} \mathrm{H}-\mathrm{NMR}$ analysis of 1,2-bis(2-methylallyl)disulfane}

The compound was analyzed by NMR under the optimum conditions using TMS as the standard and using the value of $7.249 \mathrm{ppm}$ for the water peak, as shown in Figure 1. The $=\mathrm{CH}_{2}$ group appeared as a split peak because the two hydrogen atoms are in a cis-trans relationship (Figure 1). The results are in agreement with the structure of 1,2-bis(2-methylallyl)disulfane. 
Figure 1. ${ }^{1} \mathrm{H}-\mathrm{NMR}$ spectrum of 1,2-bis(2-methylallyl)disulfane.

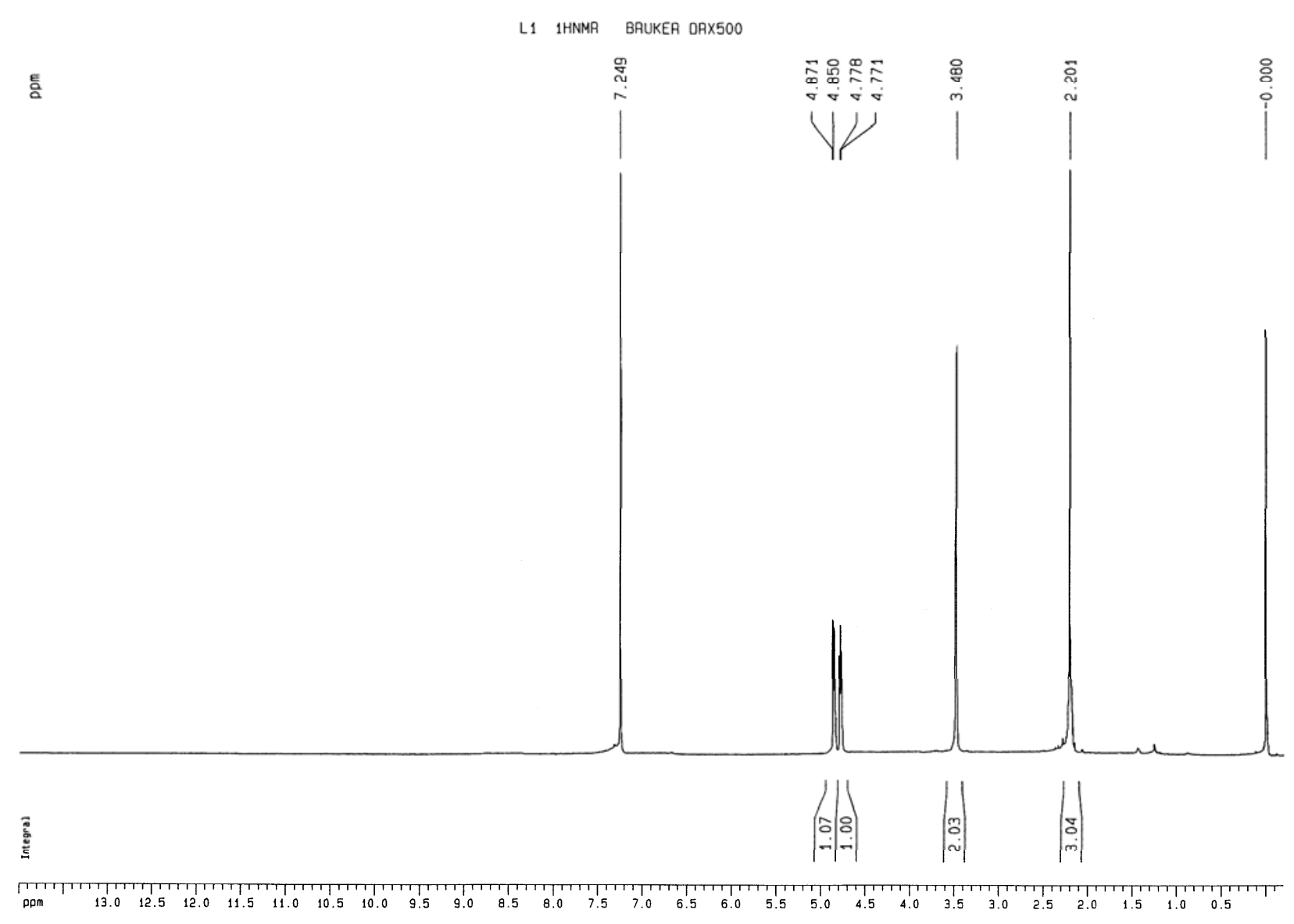

2.1.3. Elemental analysis of 1,2-bis(2-methylallyl)disulfane

The structure was also confirmed by elemental analysis, and the results are shown in Table 2 . The results were in good agreement with the formula of 1,2-bis(2-methylallyl)disulfane $\left(\mathrm{C}_{8} \mathrm{H}_{14} \mathrm{~S}_{2}\right)$.

Table 2. The elemental analysis results of 1,2-bis(2-methylallyl)disulfane.

\begin{tabular}{|c|c|c|c|}
\hline Elemental & C & H & S \\
\hline Found (\%) & 54.93 & 8.01 & 36.01 \\
\hline Calculated (\%) & 55.12 & 8.09 & 36.79 \\
\hline
\end{tabular}

2.2. The effect of 1,2-bis(2-methylallyl)disulfane on human HepG2 cells

\subsubsection{Cell activity}

Cell viability was determined by the MTT assay. As shown in Figure 2, when human HepG2 cells were exposed to drug concentrations of $0,50,100$ and $150 \mu \mathrm{mol} / \mathrm{L}$ for $24 \mathrm{~h}$, the corresponding dose-dependent inhibition ratios were $11.63 \%, 23.01 \%$ and $43.47 \%$, respectively. (Figure 2). 
Figure 2. MTT assay results.

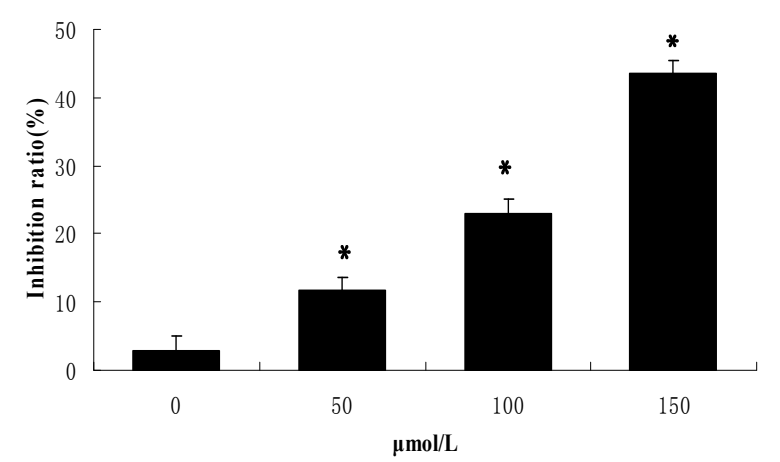

Data are expressed as mean \pm S.D and evaluated by one-way analysis of variance (ANOVA). Results are representative of three replicates $(* \mathrm{P}<0.01)$.

\subsubsection{Flow-cytometric analysis of apoptosis}

To further examine the effects of 1,2-bis(2-methylallyl)disulfane on apoptosis, flow cytometry was used to quantify the apoptotic state (Figures 3 and 4). After treatment and incubation for $24 \mathrm{~h}$, the apoptosis ratio of cells treated with $50 \mu \mathrm{mol} / \mathrm{L}, \quad 100 \mu \mathrm{mol} / \mathrm{L}$ and $150 \mu \mathrm{mol} / \mathrm{L}$ 1,2-bis(2-methylallyl)disulfane was $11.97 \%, 23.49 \%$ and $43.69 \%$ respectively. The results also supported the notion that 1,2-bis(2-methylallyl)disulfane induced apoptosis of HepG2 cells in a concentration-dependent manner.

Figure 3. Effects of each group on apoptosis in in human HepG2 cells.

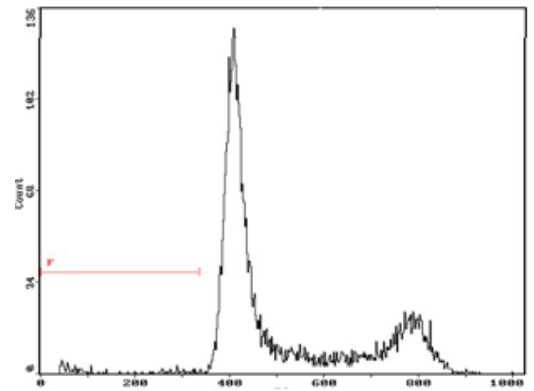

A

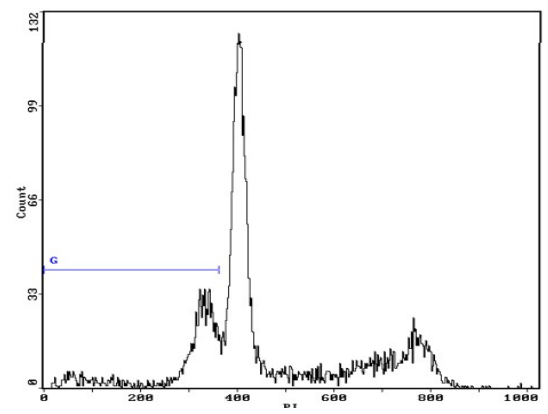

C

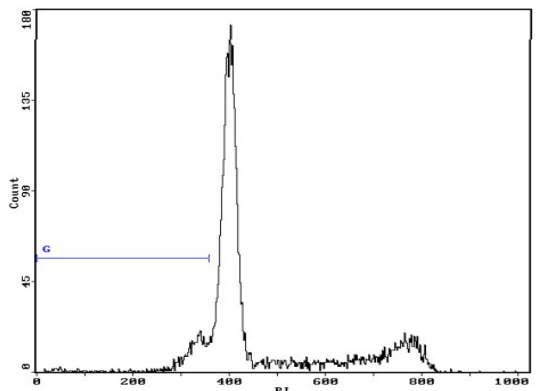

B

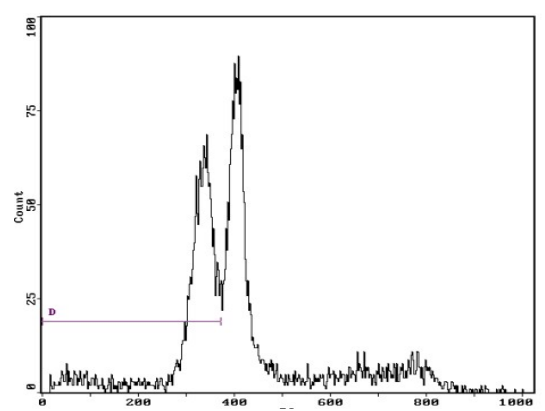

D

A. Control (untreated), B. 1,2-bis(2-methylallyl)disulfane ( $50 \mu \mathrm{mol} / \mathrm{L})$, C. 1,2-bis(2-methylallyl)disulfane $(100 \mu \mathrm{mol} / \mathrm{L})$, D. 1,2-bis(2-methylallyl)disulfane $(150 \mu \mathrm{mol} / \mathrm{L})$. The results are representative of three independent experiment. 
Figure 4. Results of the flow cytometry analysis.

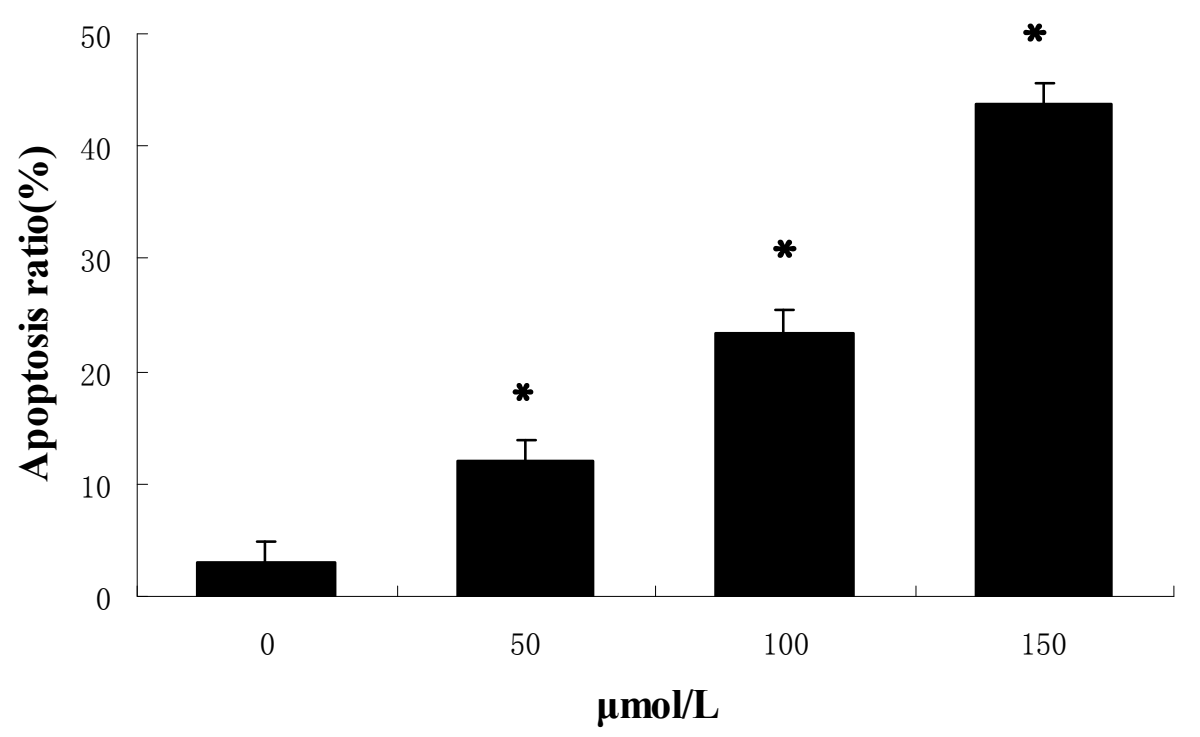

Data are expressed as mean \pm S.D and evaluated by one-way analysis of variance (ANOVA). Results are representative of three replicates $(* \mathrm{P}<0.01)$.

\subsubsection{Protein expression}

After treatment with 1,2-bis(2-methylallyl)disulfane (50,100, $150 \mu \mathrm{mol} / \mathrm{L}$, respectively) for $24 \mathrm{~h}$, the caspase-3 zymogen protein bands became thinner (Figure 5). Studies have proved that the unactivated caspase- 3 will trigger apoptosis when it is activated and play a very important role as the central effector of apoptosis when cells start apoptosis. Our results showed that 1,2-bis(2-methylallyl)disulfane could significantly enhance the activity of caspase-3 (Figure 6).

Figure 5. Effect of 1,2-bis(2-methylallyl)disuelfane on the protein expression by Western blot.

\section{Caspase-3 \\ $\alpha$-tubulin}

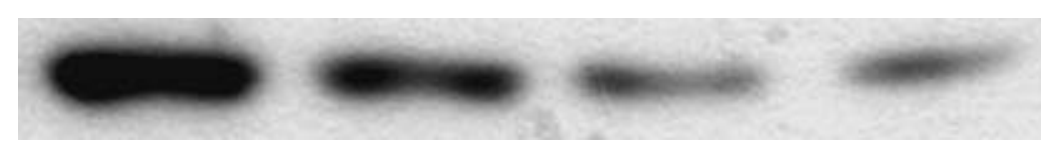

\section{1} 2 3 4

Lane 1: Control; Lane 2-4: 1,2-bis(2-methylallyl)disulfane 50, 100, $150 \mu \mathrm{mol} / \mathrm{L}$, respectively. 
Figure 6. Protein expression results.

$\square$ Caspase-3 a-tubulin

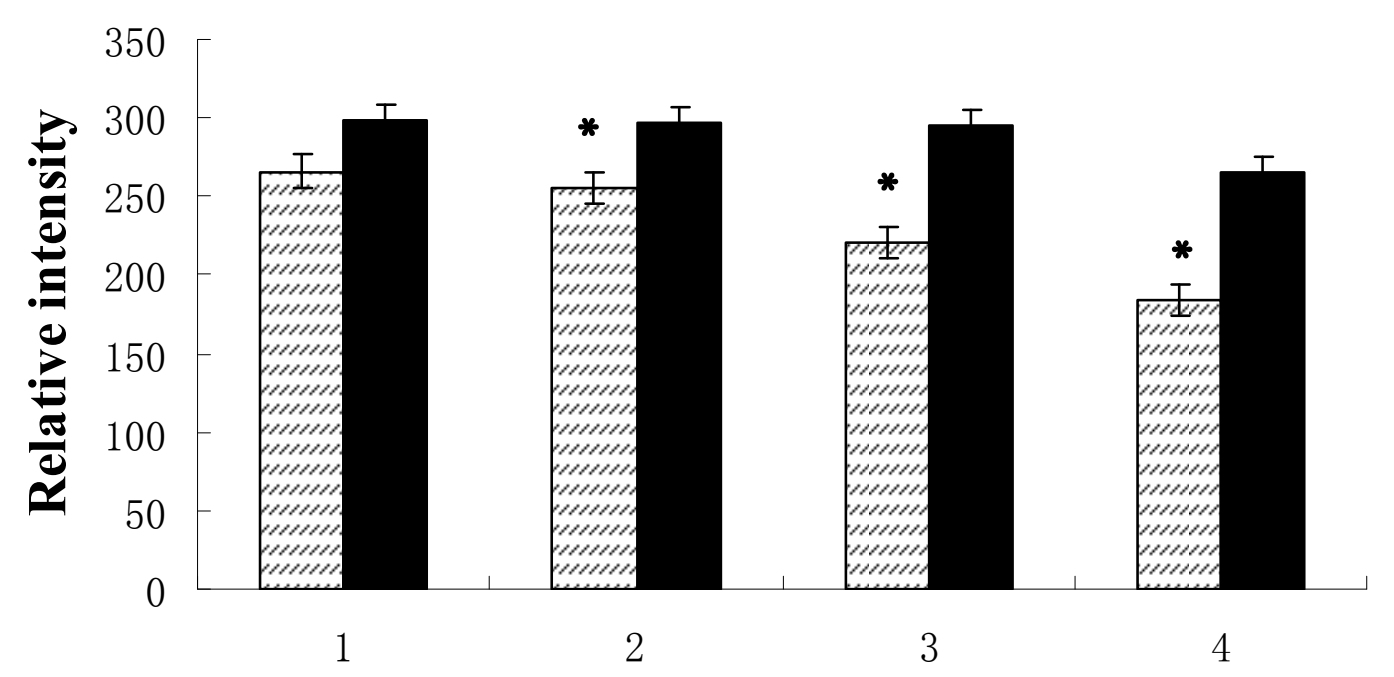

Data are expressed as mean \pm S.D and evaluated by one-way analysis of variance (ANOVA). Results are representative of three replicates $(* \mathrm{P}<0.01)$.

\section{Experimental}

\subsection{General}

3-Chloro-2-methylpropylene, 1-bromo-4-methyl-2-amylene and 1,2-dimethoxyethane (DME) were purchased from Fluka; ether, benzophenone, sulphur, chloroform and carbinol were purchaed from Nanjing Chemical Reagents Co. MTT (3-(4,5dimethylthiazol-2-yl)-2,5-diphenyltetrazolium bromide) and propidium iodide (PI) were purchased from Sigma. Caspase- 3 and $\alpha$-tubulin were purchased from Cell Signaling. DME was dried with metal sodium using benzophenone as the indicator before being used. ${ }^{1} \mathrm{H}-\mathrm{NMR}$ was recorded on a Bruker DRX-500 spectrometer at $298 \mathrm{~K}$, elementary analysis was performed on a Perkin-Elmer $240 \mathrm{C}$ analytic instrument. GC-MS analyses were performed on a HP6890 gas chromatograph equipped with a HP 5973 mass selective detector (MS), equipped with a fused-silica-capillary column, DB-5, $(30 \mathrm{~m} \times 0.32 \mathrm{~mm})$.

\subsection{Synthesis of 1,2-bis(2-methylallyl)disulfane}

The synthetic route is shown in Scheme 1. Metallic sodium sheet (12.7 g, $0.55 \mathrm{~mol})$ was added to DME (100 mL) with fast stirring, and then sulphur powder $(16.0 \mathrm{~g}, 0.50 \mathrm{~mol})$ added after the sodium metal was completely dispersed, and the mixture was stirred at the room temperature for $2 \mathrm{~h}$, until the $\mathrm{Na}_{2} \mathrm{~S}_{2}$ was formed. The product was kept sealed in cool place [13-15]. $\mathrm{Na}_{2} \mathrm{~S}_{2}(50 \mathrm{~mL})$ was added into a round bottom flask $(250 \mathrm{~mL})$, then DME $(50 \mathrm{~mL})$ which contained 3-chloro-2-methylpropylene (45 g, $0.50 \mathrm{~mol}$ ) was added dropwise to the round bottom flask with continuous stirring, and the mixture was reacted in a $70{ }^{\circ} \mathrm{C}$ oil bath for $4 \mathrm{~h}$. After completing the reaction, the solvent was removed by rotary evaporator to give a bright yellow oily substance. The oily product was added into distilled water $(50 \mathrm{~mL})$ and dispersed with ultrasound, then extracted with ether $(20 \mathrm{~mL} \times 5)$, and extracted with 
chloroform three times. The combined extracts were evaporated under vacuum to remove the solvent. Then using chloroform/methanol $(\mathrm{v} / \mathrm{v}=95 / 5)$ as mobile phase, the product was purfied by silica gel column chromatography[16-20]. A yllow oil was obtained (56.86 g, 65.3\% yield). 'H-NMR: $\left(\mathrm{CDCl}_{3}\right) \delta$ (ppm): 4.771-4.871 (4H, d, =CH2), $3.480\left(4 \mathrm{H}, \mathrm{s},-\mathrm{CH}_{2}\right), 2.201\left(6 \mathrm{H}, \mathrm{s},-\mathrm{CH}_{3}\right)$.

The synthetic route is shown as follows:

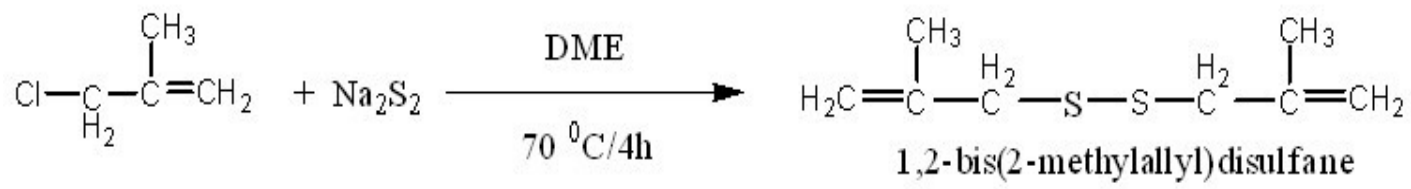

\subsection{Cell culture}

HepG2 cells, a human hepatoma cell line, was cultured at $37^{\circ} \mathrm{C}$ in DMEM with $10 \%$ heat-inactivated fetal bovine serum (FBS), benzylpenicillin $(100 \mathrm{kU} / \mathrm{L})$ and streptomycin $(100 \mathrm{mg} / \mathrm{L})$ in an incubator containing humidified air with $5 \% \mathrm{CO}_{2}$.

\subsection{Cell viability assay}

Cells were seeded into 96 -well plates at $1 \times 10^{4}$ cells per well $24 \mathrm{~h}$ before treatment. The cultures were then rinsed in phenol-free DMEM medium and incubated with respective test substances in phenol-free and serum free DMEM for $24 \mathrm{~h}$. In the inhibition test, cells were treated with 1,2-bis(2-methylallyl)disulfane. At the end of this time interval, $20 \mu \mathrm{L}(5 \mathrm{mg} / \mathrm{mL}) \mathrm{MTT}$ (3-(4,5dimethylthiazol-2-yl)-2,5-diphenyltetrazolium bromide) was added to each well, and after incubation at $37^{\circ} \mathrm{C}$ for $4 \mathrm{~h}$ the MTT solution was removed and $200 \mu \mathrm{L}$ of dimethylsulfoxide (DMSO) was added to dissolve the crystals. The absorbance of each well was measured at $570 \mathrm{~nm}$.

\subsection{Flow cytometry analysis}

Cells were seeded into $100-\mathrm{mL}$ cell culture bottles at $12 \times 10^{6}$ cells $24 \mathrm{~h}$ before treatment. Then cells were treated according to the aforementioned method and incubated for $24 \mathrm{~h}$. Afterwards, cells were collected, combined into single cell suspension and centrifuged at $800 \times \mathrm{g}$ for $5 \mathrm{~min}$. The supernatant was discarded and the cells were washed three times with cooled PBS and fixed for $24 \mathrm{~h}$ with cold alcohol at $4{ }^{\circ} \mathrm{C} .1 \mathrm{~mL}$ cell suspension $\left(10^{6} / \mathrm{mL}\right)$ was washed three times with the cool PBS, treated with RNase for $30 \mathrm{~min}$ at $37^{\circ} \mathrm{C}$, stained it with PI for $30 \mathrm{~min}$ at $37{ }^{\circ} \mathrm{C}$ in a dark environment, and taken for flow cytometry analysis.

\subsection{Western-blotting}

The cells were taken in the logarithmic growth phase, treated according to the aforementioned method and incubated for $24 \mathrm{~h}$. After fragmentation on ice for $20 \mathrm{~min}$, the lysates were centrifuged at $15,000 \times \mathrm{g}$ for $10 \mathrm{~min}$ at $4{ }^{\circ} \mathrm{C}$, the protein was collected, quantitated with the BCA method, electrophoresed and isolated by the SDS-PAGE (10\%) using the electrotransfer method, blocked and 
hybridized on the cellulose nitrate film. The the protein expression of cells was detected using the ECL Western blotting method. The densities of protein bands were calculated using the Quantity One software.

\subsection{Statistics}

Data are expressed as mean \pm S.D of three independent experiments and were evaluated by one-way analysis of variance (ANOVA). Significant differences were established at $\mathrm{P}<0.05$.

\section{Conclusions}

1,2-bis(2-methylallyl)disulfane was prepared and characterized by GC-MS, ${ }^{1} \mathrm{H}-\mathrm{NMR}$ and elemental analysis. The cell viability assay, flow-cytometric analysis of apoptosis and protein expression showed that 1,2-bis(2-methylallyl)disulfane could significantly inhibit proliferation and induce apoptosis in a dose dependent manner in human HepG2 cells.

\section{References}

1. Sundaram, S.G.; Milner, J.A. Diallyl disulfide induces apoptosis of human colon tumor cells. Carcinogenesis 1996, 17, 669-673.

2. Kwon, K.B.; Yoo, S.J.; Ryu, D.G.; Yang, J.Y.; Rho, H.W.; Kim, J.S. Induction ofapoptosis by diallyl disulfide through activation of Caspase-3 in human leukemia HL-60 cells. Biochem. Pharmacol. 2002, 63, 41-47.

3. Nakagawa, H.; Tsuta, K.; Kiuchi, K.; Senzaki, H.; Tanaka, K.; Hioki, K. Growth inhibitory effects of diallyl disfulfide on human breast cancer cell lines. Carcinogenesis 2001, 22, 891-897.

4. Wen, J.; Zhang, Y.W.; Chen, X.Q.; Shen, L.B.; Li, G.C.; Xu, M. Enhancement of diallyl disulfide-induced apoptosis by inhibitors of MAPKs in human HepG2 hepatoma cells. Biochem. Pharmacol. 2004, 68, 323-331.

5. Druesne-Pecollo, N.; Pagniez, A.; Thomas, M.; Cherbuy, C.; Duee, P.H.; Martel, P.; Chaumontet, C. Diallyl Disulfide Increases CDKN1A Promoter-Associated Histone Acetylation in Human Colon Tumor Cell Lines. Agric. Food Chem. 2006, 54, 7503-7507.

6. Bottone, F.G., Jr.; Baek, S.J.; Nixon, J.B.; Eling, T.E. Diallyl disulfide (DADS) induces the antitumorigenic NSAID-activated gene (NAG-1) by a p53 dependent mechanism in human colorectal HCT 116 cells. J. Nutr. 2002, 132, 773-778.

7. Hong, Y.S.; Ham, Y.A.; Choi, J.H.; Kim, J. Effects of ally sulfur compounds and garlic extract on expressions of Bc122, Bax, and p53 in nonsmall cell lung cancer cell lines. Exp. Mol. Med. 2000, 32, 127-134.

8. Tsai, C.W.; Chen, H.W.; Yang, J.J.; Sheen, L.Y.; Lii, C.K. Diallyl Disulfide and Diallyl Trisulfide Up-Regulate the Expression of the $\pi$ Class of Glutathione S-Transferase via an AP-1-Dependent Pathway. Agric. Food Chem. 2007, 55, 1019-1026.

9. Nabekura, T.; Kamiyama, S.; Kitagawa, S. Effects of dietary chemopre2 ventive phytochemicals on P-glycoprotein function. Biochem. Biophys. Res. Commun. 2005, 327, 866-870. 
10. Xiao, D.; Choi, S.; Johnson, D.E. Diallyl trisulfide - induced apoptosis in human prostate cancer cells is mediated by activation of c-Jun N-terminal kinase and extracellular-signal regulated kinase mediated phosphoryl ation of Bcl-2. Oncogene 2004, 23, 5594-5606.

11. Srivastava, A.; Akoh, C.C.; Fischer, J.; Krewer, G. Effect of Anthocyanin Fractions from Selected Cultivars of Georgia-Grown Blueberries on Apoptosis and Phase II Enzymes. Agric. Food Chem. 2007, 55, 3180-3185.

12. Zhang, E.J.; Ng, K.M.; Luo, K.Q. Extraction and Purification of Isoflavones from Soybeans and Characterization of Their Estrogenic Activities. Agric. Food Chem. 2007, 55, 6940-6950.

13. Toshikazu, T.; Daisaku, S.; Yoshimasa, M.; Nobuo, Y.; Nobuhiro, K. Aromatic Hydrocarbon-Catalyzed Direct Reaction of Sulfur and Sodium in a Heterogeneous System: Selective and Facile Synthesis of Sodium Monosulfide and Disulfide. Inorg. Chem. 2003, 42, 3712-3714.

14. Yoon, H.; Liu, R.H. Effect of Selected Phytochemicals and Apple Extracts on NF-кB Activation in Human Breast Cancer MCF-7 Cells. Agric. Food Chem. 2007, 55, 3167-3173.

15. Dorant, E.; Van den Brandi, P.A.; Goldbohm, R.A.; Hermus, R.J.; Sturmans, F. Garlic and its significance for the prevention of cancer in humans. Br. J. Cancer 1993, 67, 424-429.

16. Kern, M.; Pahlke, G.; Balavenkatraman, K.K.; Bohmer, F.D.; Marko, D. Apple Polyphenols Affect Protein Kinase C Activity and the Onset of Apoptosis in Human Colon Carcinoma Cells. Agric. Food Chem. 2007, 55, 4999-5006.

17. Gedye, R.; Smith, F.; Westaway, K.; Ali, H.; Baldisera, L.; Laberge, L.; Rousell, J. The use of microwave ovens for rapid organic synthesis. Tetrahedron Lett. 1986, 27, 279-282.

18. Hansen, M.B.; Nielsen, S.E.; Berg, K. Re-examination and further development of a precise and rapid dye method for measuring cell grewth/cell kill. Immunol. Meth. 1989, 119, 203-210.

19. Gerard, M.; Michael, F. Organoleptic characteristics of flavor materials. Perfumer Flavorist 1992, $17,41-42$.

20. Roman, K.; Jan, V. Sulfur-containing volatiles arising by thermal degradation of alliin and deoxyalliin. J. Agric. Food Chem. 1997, 45, 3580-3585.

Sample Availability: Samples of the compounds are available from the authors.

(C) 2010 by the authors; licensee MDPI, Basel, Switzerland. This article is an Open Access article distributed under the terms and conditions of the Creative Commons Attribution license (http://creativecommons.org/licenses/by/3.0/). 